\title{
A extinção dos brasileiros segundo o conde Gobineau
}

\section{The extinction of the Brazilian according to count Gobineau}

\author{
RICARDO ALEXANDRE SANTOS DE SOUSA
}

Casa de Oswaldo Cruz | COC/FIOCRUZ

\begin{abstract}
RESUMO Joseph Arthur de Gobineau, o conde Gobineau, veio ao Brasil no ano de 1869 em missão diplomática. Era um literato com vasta produção, porém os quatro volumes do Essai sur l'inégalité des races humaines - Ensaio sobre a desigualdade das raças humanas foram o seu trabalho mais conhecido.

Na citada obra, o conde procurava compreender a causa da ascensão e queda das grandes civilizações e chegara à conclusão de que a questão étnica era a mola propulsora da história. A mistura de raças seria, portanto, a razão para o fim das grandes civilizações. Nesse caso, os brasileiros não seriam dignos de um bom prognóstico por parte do conde, o qual acreditava que em menos de duzentos anos essa população seria extinta.
\end{abstract}

Palavras-chave raça-progresso - mestiçagem - civilização - degenerescência.

\begin{abstract}
Joseph Arthur de Gobineau, the Count Gobineau, came to Brazil in 1869 on a diplomatic mission. He was a man of letters with vast production, but his best-known work is the Essaisurl'inégalitédes races humaines-The inequality of human races, which sought to understand the cause of rise and fall of all great civilization. He concluded that ethnic issue was the spring propulsion for history. For him the reason of the collapse of great civilization was the mixing of races. Considering that, Brazilians could not expect a good prognosis of Gobineau who believed that this people would be extinct in less than two hundred years.
\end{abstract}

Keywords race-progress - mestizo - civilization - degeneration.

\section{Introdução}

Segundo o conde francês Joseph Arthur de Gobineau, em artigo escrito para o periódico francês Le Correspondant, no ano de 1874, intitulado L'émigration au Brésil, os brasileiros seriam uma raça extinta em menos de duzentos anos. Isso por serem, em sua maioria, uma população mestiça, fruto da mestiçagem entre índios, negros e um pequeno número de portugueses.

Mais do que procurar provar, que tanto o mau prognóstico quanto a impressão tida por Gobineau acerca dos brasileiros seria falsa, vale investigar em que bases da ciência oitocentista tais afirmações tão ousadas eram feitas. Para isso é preciso conhecer melhor a história do controverso e cáustico conde Gobineau e sua formação.

0 francês esteve no Brasil em missão diplomática no ano de 1869, quando foi designado ministro plenipotenciário da França na corte brasileira, o que corresponde atualmente ao cargo de embaixador. Gobineau tudo fez na tentativa de escapar à incumbência de representar a França no Brasil, mas todo o seu esforço foi em vão. Com essa disposição de espírito, assumiu seu novo posto e, para sua surpresa, foi recebido pelo imperador brasileiro, D. Pedro II, de forma 
muito cortês. Este, já havia lido as principais obras do conde e veio a tornar-se aos olhos de Gobineau "o príncipe mais inteligente e erudito que existiu".'

Pelo menos duas vezes por semana, os dois intelectuais reuniam-se para horas de conversa sobre tudo o que se produzia no mundo das ciências e letras. Embora frequentemente discordassem, tais conversas selaram uma amizade sincera que perdurou até a morte de Gobineau, em 1882.

Se a erudição do imperador surpreendera positivamente o conde, o mesmo não se pode dizer acerca dos brasileiros. A miscigenação de raças produzira-lhe desagradável impressão frequentemente expressa pelo diplomata em atitudes e palavras:

Já não existe nenhuma família brasileira que não tenha sangue negro e índio nas veias; o resultado são compleições raquíticas que, se nem sempre repugnantes, são sempre desagradáveis aos olhos.

Aos olhos de Gobineau, além de se mostrarem "esteticamente repugnantes", os brasileiros carregavam defeitos ainda mais graves, como o de serem avessos ao trabalho, "evitam mover uma palha para fazer qualquer coisa de útil, até mesmo para se afogarem", ${ }^{3}$ dados a vícios e, também, eram pouco férteis e fisicamente enfraquecidos, o que garantiria sua diminuição e aniquilamento em menos de dois séculos.

0 artigo escrito para o Le Correspondant, citado anteriormente, intencionava atrair às terras brasileiras uma população "desejável", a fim de substituir a população "degenerada" que caminhava a passos largos para o desaparecimento (Sousa, 2008). Felizmente, nós brasileiros escapamos ao prognóstico fatídico que nos apontava o conde, visto que a população vem crescendo desde 1873, quando foi escrito 0 artigo, até os nossos dias. ${ }^{4}$

\section{Gobineau e sua formação}

Joseph Arthur de Gobineau nasceu em 14 de julho de 1816, era filho de Louis de Gobineau e de Anne Madeleine de Gercy. Esta partiu com os dois filhos, Joseph Arthur - então com 14 anos - e Caroline para viver na Suíça com um jovem dandy, Charles Sotin de La Condière, preceptor do jovem Gobineau. A nova família viveu em Bienne, onde 0 adolescente Gobineau baseou seus estudos em clássicos, latim e grego. Posteriormente, Gercy, seu companheiro e seus filhos foram viver na Alemanha.

Gobineau voltou ao convívio do pai no fim da adolescência. Todavia, por pouco tempo, já que em vez de seguir a vida militar, sonhada por Louis de Gobineau, preferiu ir para Paris tentar a carreira literária.

Na capital francesa morou com o tio paterno Thibaut-Joseph. Contudo, a recepção por parte do parente não foi propriamente amistosa. 0 tio passou três semanas sem sequer dirigir a palavra ao sobrinho. Como paciência não era uma das maiores virtudes do jovem Gobineau, ele partiu para o confronto direto, questionando a razão pela qual recebia esse tratamento por parte do tio.

0 resultado foi surpreendente. Não somente Thibaut-Joseph mudou a sua disposição com o rapaz, como fez dele o seu único herdeiro. Foi com essa herança que, mais tarde, Gobineau adquiriu o castelo de Trye na região de Oise na França, o único bem com o qual ele e sua esposa Clémence Monnerot, com quem casou em 1846, contaram por toda sua vida conjugal.

De acordo com um dos biógrafos do conde, a partícula "de" no nome do conde, que caracterizaria sua origem nobre, tão cara a Gobineau, não seria advinda da pia batismal. Talvez por isso ele tenha, aos 55 anos, escrito um romance chamado Histoire d'Ottar-Jarl, um viking normando descendente do deus Odin. No citado romance, o próprio Gobineau, por linhagem de sangue aristocrática e cavalheiresca seria descendente direto de Ottar-Jarl. ${ }^{5}$ Essa afirmação 
não chegou a causar surpresa aos amigos mais próximos do conde, como o imperador brasileiro D. Pedro II, conforme atestou em carta escrita a Gobineau em dezembro de 1879:

Bem tinha previsto que devíeis ser descendente de Ottar-Jarl. Vosso livro interessa-me muito. Aí descreveis, em largos traços, a idade média, e lendo o nome de Froissard, lembrava-me das mais atraentes leituras da minha mocidade. ${ }^{6}$

0 conde era um típico literato, avesso às especializações que definia os diversos campos das ciências na segunda metade do século XIX. Dessa forma, emprestava sua erudição tanto a trabalhos literários como a poesia, romances, novelas e também a antropologia social, e, já em idade avançada, passou a atuar como escultor, produzindo algumas obras por encomenda do imperador brasileiro. ${ }^{7}$ Atualmente, contudo, Gobineau é mais conhecido, não por seus dotes artísticos, mas pelo Essai sur l' inégalité des races humaines. ${ }^{8}$ Uma obra em quatro volumes, na qual procurava especular a razão da ascensão e queda de todas as grandes civilizações. A tese de Gobineau era de que a questão étnica seria a responsável pelo declínio de civilizações que outrora floresceram. Esse fato se dava porque uma raça originalmente pura ao misturar-se com outras se tornava degenerada, perdia as suas qualidades essenciais, levando essa civilização ao declínio.

Evidentemente 0 conde Gobineau, partindo do princípio básico de sua teoria, não tinha qualquer motivo para pensar que haveria um futuro promissor aos brasileiros, porquanto a miscigenação racial era disseminada e evidente nessa população.

0 amigo, imperador brasileiro, por mais que desfrutasse da erudição do conde, com o qual se correspondeu por onze anos após a volta deste para o Velho Continente, não partilhava das suas crenças raciais, pelo menos de forma tão absoluta, à medida que atestava em carta datada de 15 de novembro de 1879, "(...) como sabeis, não protesto senão contra o que julgo ser muito absoluto em vossa doutrina sobre as raças humanas". ${ }^{9}$

Outro grande amigo e oponente mais incisivo de Gobineau foi o homem que the deu a maior oportunidade de sua vida, lançando-0 na carreira diplomática: Alexis de Tocqueville. Este conheceu Gobineau por volta de 1842, ainda em Paris, quando o jovem se tornara colaborador do jornal Commerce. Tocqueville, reconhecendo o talento do rapaz, o convidou para elaborar um trabalho na Académie des Sciences Morales e Politiques sobre a aplicação das doutrinas morais à política e à administração no século XIX.

Naquele período, o pensamento do jovem Gobineau se distanciava muito da perspectiva racialista que o caracterizou alguns anos mais tarde. Tocqueville, mais velho, já era um crítico à Revolução Francesa. A queda do Regime Monárquico teria, a seu ver, destruído um edifício social que, inevitavelmente, haveria de ruir sem arrasar os fundamentos da sociedade, tal como aconteceu com o processo revolucionário. Em outras palavras, Tocqueville encarava a revolução como desnecessária e prejudicial por destruir tradições seculares sem erguer nada de consistente em seu lugar. Isso transformava a sociedade em indivíduos que compunham uma massa disforme e confusa.

Não há mais hierarquia na sociedade, nem classes determinadas, nem posições fixas: há um povo composto de indivíduos quase semelhantes e inteiramente iguais, uma massa confusa reconhecida como o único soberano legítimo, mas cuidadosamente privada de todas as faculdades que poderiam permitir-Ihe dirigir e até controlar seu governo. ${ }^{10}$

Contra essa sociedade massificada, formada por indivíduos sem hierarquia ou tradição, Gobineau também se posicionava de forma veemente. Porém, enquanto Tocqueville pensava o caso francês como diferenciado do inglês ou do americano e achava que cada um merecia uma análise dos fatores locais que causaram o surgimento da sociedade moderna e da democracia, Gobineau acreditava haver uma razão geral que fosse comum a todos os casos e que explicasse a história da humanidade como um todo. 


\section{O argumento racial de Gobineau em seu Essai}

Gobineau destinou grande parte de sua energia intelectual buscando na história a causa da ascensão e queda das grandes civilizações. Conforme comunicouno Essai, "o tribunal da história é o único competente". ${ }^{11}$ Desse modo, procurou analisar em sua obra as grandes civilizações consagradas pela história europeia de seu tempo, suas ascensões e declínios.

Várias hipóteses são levantadas como causa da decadência das civilizações. Argumentos que o próprio Gobineau tratava de lançar por terra em uma costura retórica que visava a conduzir o leitor ao ponto central de seu argumento, as diferenças raciais.

Diversos exemplos são citados no Essai como possíveis causadores da decadência dos povos. 0 fanatismo era uma das situações refutadas, uma vez queas civilizações, como a dos astecas,teriam sido ricas e poderosas justamente no período em que sacrificavam frequentemente vidas humanas aos seus deuses. Talvez o luxo e a preguiça fossem então a causa da destruição, todavia para isso haveria o contra-argumento de que Rússia, Inglaterra, França e Alemanha, a despeito destes graves defeitos, seriam grandes potências ou, ainda no período medieval, os venezianos, genoveses e pisanos que viviam o apogeu justamente quando o luxo e a preguiça eram defeitos evidentes. Quem sabe, então, fosse a corrupção de costumes a causa do mal. Porém, contra essa suspeita, Gobineau lembrava-se dos romanos, dos Bórgia ou mesmo dos espartanos na antiguidade, povos que "apesar da corrupção de costumes não sucumbiram à decadência por esse motivo". No caso dos romanos, asseverou haver uma coincidência entre o apogeu de seu poder e uma grande corrupção de costumes, inversamente quando o cristianismo os libertou da corrupção foi que experimentaram a decadência.

Outra causa provável seria o abandono dos preceitos religiosos, o que, na sua concepção, não se susteria, porque os persas (Tiro, Cartago e Judeia), assim como os astecas e os incas eram bastante apegados a seus cultos nacionais quando vieram a desaparecer como nação. Os maus governos também eram cogitados como hipótese, porém descartada com a citação de que muitos povos emergem mais coesos e fortes após um período de tirania.

Em determinado momento da análise, o conde chegou a propor que uma civilização envelhecida seria inevitavelmente traspassada por outra mais jovem, da mesma maneira que a Caldeia envelhecida pela vigorosa Pérsia; ou a Grécia decrépita pela Roma viril; ou ainda a bastarda dominação de Augusto pelo Reino dos Nobres e Príncipes Teutônicos. Nesse ponto, entretanto, 0 autor dá a guinada definitiva, chegando à proposição que marcará toda sua análise daí por diante:

Então foi quando de induções em induções tive de me deixar convencer da evidência: que a questão étnica domina todos os demais problemas da história, constitui sua chave, e a desigualdade das raças, cujo concurso forma uma nação, basta para explicar todo o encadeamento do destino dospovos. ${ }^{12}$

Essa é, portanto, a chave encontrada pelo conde ao explicar a razão da decadência de todas as civilizações que um dia experimentaram o apogeu: a questão étnica seria para ele o dado fundamental à compreensão de todos os problemas da história.

Uma civilização, que outrora fora vigorosa, se encontraria assim enfraquecida devido ao cruzamento com outras raças. Isso, no entanto seria inevitável, pois à medida que determinado povo cresce e se fortalece, tende a conquistar outros povos. Conquistadores e conquistados fatalmente sofreriam um processo de miscigenação, gerando uma prole que não guardaria as mesmas qualidades das raças originais. ${ }^{13}$ 


\title{
Tocqueville, um sábio amigo
}

Em outubro de 1853, Gobineau enviou ao amigo Tocqueville os dois primeiros volumes do Essai, que ainda estava escrevendo, para que o intelectual, mais experiente, desse suas impressões. Com essa obra, ele pretendia concorrer a uma cadeira na Académie des Sciences Morales et Politiques, e, sendo assim, contava com o apoio e os bons contatos de Tocqueville.

A reação de Tocqueville foi bastante desanimadora, consoante se pode perceber na resposta do primeiro à consulta de Gobineau durante a elaboração de seu Essai:

Mas é evidentemente o contrário. Que interesse pode haver em persuadir as pessoas que vivem na barbárie, na apatia ou na servidão, que assim se encontram por força da natureza da raça e que nada se pode fazer para melhorar suas condições, mudar seus costumes ou modificar seus governos? Não vê que vossa doutrina libera todo o mal da desigualdade permanente. O orgulho, a violência, o desprezo ao semelhante, a tirania e a abjeção em todas as suas formas? ${ }^{14}$.

Tocqueville, como mencionado, era crítico à Revolução e avesso à sociedade individualista e massificada que, segundo 0 autor, dela seria recorrente. Contudo, não acreditava haver uma causa única para os males da humanidade e, menos ainda, ser o fator racial determinante como queria Gobineau.

Além disso, o amigo mais experiente percebia os perigos ocultos na proposta do conde e que foram tão bemrelacionados no trecho da carta em destaque. Nela tenta dissuadir Gobineau a dar novos rumos a seus estudos, pois os que escolhera mostravam-se extremamente perigosos e nocivos ao convívio social.

A má impressão do amigo não desestimulou Gobineau, que levou avante seu intento de escrever o Essai, e, posto que Tocqueville não aprovasse os fundamentos de suas ideias, indicou a ele o nome de vários membros da Academie des Science Morales et Politiques para os quais o Essai poderia ser enviado. A impressão que tais membros tiveram, com duas raras exceções, não foram muito diferentes daquela que Tocqueville expressara anteriormente, como se queixava Gobineau em carta ao amigo em 7 de março de 1854.

\begin{abstract}
Não é possível dizer, como faz sr. Reinhart, que eu não seria nem mesmo capaz de copiar, ou como repete o sr. Fénelon, que com exceção dos chineses minha obra para nada serve. De hoje em diante, como vós justamente bem advertistes, minha posição será me resguardar. Nada me resta a fazer. Felizmente, minhas inclinações se encontraram do lado da sabedoria e as coisas irão, portanto, andar por si só. Por outro lado, encontrei por parte do sr. Tallenay uma forte acolhida. Muito amavelmente o sr. Cintrat lhe escreveu uma benevolente carta a meu respeito. ${ }^{15}$
\end{abstract}

\section{O diálogo de Gobineau com a cultura e a ciência de seu tempo}

Ao conduzir o leitor por um caminho mental, o qual supostamente teria percorrido para chegar à conclusão de que era a questão étnica a mola propulsora do progresso e da decadência dos povos, seu pensamento não era tão original quanto pretendia fazer crer. A interpretação da história francesa a partir do embate entre francos e galo-romanos, assim como Gobineau propunha no Essai, era algo com o qual os franceses já se encontravam bastante familiarizados, mesmo que nem sempre a conotação racial fosse a tônica desse discurso.

De acordo com a crença popular, os francos teriam dado origem à nobreza, enquanto os galo-romanos ao terceiro estado. 0 próprio François Guizot (1787-1874), ministro da Instrução Pública, partilhava a crença de que a Revolução teria sido um embate entre dois povos. "Francos e Gauleses, senhores e camponeses". Era como se todos se reco- 
nhecessem franceses e tivessem igualmente a França por pátria, mas retornassem enfim à velha querela de mais de treze séculos antes. ${ }^{16}$

Tal como Guizot, outros historiadores pós-revolucionários como Thierry e Michelet esforçavam-se por construir uma nova identidade à França pós-revolucionária, valorizando a origem galo-romana frente à origem germânica dos francos.

Gobineau, embora pensasse ser a população franco-germânica superior em muitos aspectos, partilhava a crença de que os galo-romanos dos séculos V e VI, ainda que conquistados, eram uma raça valiosa e superior a seus conquistadores no que diz respeito à moral, bravura e gênio militar. Porém, evitava a visão de que essa raça originara uma classe específica da sociedade. Antes, acreditava que os séculos VIII e IX trouxeram uma mistura de raças entre conquistadores e conquistados que tendeu a se intensificar nos séculos seguintes, trazendo como resultado, já nos séculos XIV e XV, o predomínio da bandidagem e decadência, ou seja, até mesmo a raça conquistada acabava por perder as qualidades que possuía antes da miscigenação.

Toda a sociedade, mesmo a de seu país, estaria condenada pelo cruzamento de raças. Não existiria, na visão de Gobineau, a possibilidade de se manter a pureza de raça que iniciara uma grande civilização. Todas estariam condenadas pela degenerescência.

Penso, pois, que a palavra degenerado, ao aplicar-se a um povo, deve significar e significa que este povo já não possui o valor intrínseco que antigamente possuía, porque já não circula em suas veias o mesmo sangue, gradualmente depauperado com as sucessivas misturas. Dito de outra maneira, que com o mesmo nome não conservaram a mesma raça que seus fundadores; enfim, que o homem da decadência, que chamamos degenerado, é um produto diferente do ponto de vista étnico do herói das grandes épocas. ${ }^{17}$

Mesmo a França, seu país de origem, e as demais nações europeias não seriam poupadas da visão pessimista do conde Gobineau. Todas estavam fadadas à degenerescência devido à mistura racial que era inevitável, todavia levava a espécie humana ao declínio. 0 Brasil, nessa visão fatalista, encontrava-se adiantado no processo de decadência.

Desde o século XVIII, a fisiologia vinha se desenvolvendo bastante no continente europeu, fornecendo novos campos de estudos aos homens das ciências e das letras que procuravam compreender a sociedade. 0 conceito de raça, deslocado do argumento teológico ou do mito fundador da nação, passava a calcar-se no caráter biológico e hereditário na nova perspectiva da fisiologia.

Gobineau, que era um típicohomem de letras, não se encontrava alheio à discussão da sua época. 0 conde de Saint-Simon teria afirmado anos antes que: "A fisiologia ainda não merece ser classificada entre as ciências positivas, mas só tem um passo a dar" (Saint-Simon apud Poliakov, 1974). Pensadores como Cabanis, Bichar e Vicq d'Azyr garantiam o respaldo à nova ciência que afastava as explicações das nações e suas origens do tema teológico. ${ }^{18}$

Pierre Cabanis foi um dos mais representativos pensadores da nova geração revolucionária. Em sua obra redigida em 1795-1798, Rapports du Physique et du moral de l'homme, ainda no calor pós-revolucionário, propunha que a mescla de raças seria uma forma de "ousar corrigir a natureza", igualando as qualidades respectivas das diferentes raças, promovendo, assim, uma espécie de igualdade dos meios que não estava na organização primitiva. ${ }^{19}$

De modo evidente, Gobineau, avesso ao sentimento otimista de igualdade entre os homens, não se filiaria a Cabanis em sua intenção de ampliar os ideais igualitários da Revolução Francesa ao plano racial.

Uma das grandes discussões entre os pensadores do século XIX era quanto à questão da origem do homem: soltas as amarras da explicação teológica e frente à descoberta de diversas outras sociedades humanas naqueles últimos três séculos, o europeu questionava se teriam todos aqueles grupos advindos de um só casal.

Estudiosos dividiam-se entre os monogenistas, crentes em uma única origem do gênero humano e poligenistas, aqueles que acreditavam haver surgido paralelamente diversos focos de hominídeos em diferentes lugares do globo. 
No Essai, Gobineau dedicou especial atenção a essa questão procurando discuti-la com diversos fisiologistas. No início do seu discurso, fez vários elogios a Pierre Camper (1722-1789), médico e naturalista holandês. Camper dedicou-se a uma série de estudos nos quais tomava medida de certos ângulos da face, tanto de seres humanos quanto de outros animais, para comprovar haver uma relação direta entre 0 aumento desse ângulo e o padrão de desenvolvimento da espécie. Segundo Camper, o europeu era o que apresentava o maior ângulo, enquanto 0 africano se aproximava de orangotangos. Apesar dessas proposições, Camper evitava tomar partido dos poligenistas.

Gobineau afirmava que Camper não se ateve a uma observação superficial e que assentou suas demonstrações na matemática, não deixando lugar à dúvida, dessa forma suas opiniões adquiriram um vigor sem o qual não haveria verdadeiramente ciência. No entanto, contrapõe-se ao argumento de Camper, chamando à discussão um de seus críticos, Richard Owen (1804-1892), biólogo inglês com estudos em anatomia comparada e em paleontologia. Owen atestava que a pesquisa de Camper havia sido feita com base em símios jovens e que as mesmas medidas em macacos adultos eram bastante variadas. Em chipanzés adultos elas chegavam a formar ângulos de 30 a 35 graus, 0 que seria uma distância considerável em relação aos africanos, que possuíam em média 70 graus. Além do mais, animais que pareciam mais inteligentes que o orangotango tinham um ângulo facial menor, como era o caso dos elefantes. Colocava-se, dessa forma, em dúvida a asserção primordial de Camper.

Outrossim, Owen fez uma série de comparações entre o cérebro de orangotangos e o cérebro humano, ao eleger características que Camper havia desprezado, as quais Ihe pareciam primordiais. 0 método de Camper também não era aplicável a todas as variedades da raça humana, visto que deixava fora de suas categorias as tribos que exibiam uma formação craniana piramidal.

Gobineau cita também Johann Friedrich Blumenbach (1752-1840) e seus estudos craniológicos, nos quais procurava avaliar o desenvolvimento humano a partir da chamada norma verticalis, que verificava a direção dos ossos maxilares e molares a partir da largura ou da estreiteza do contorno oval apresentado pelo vértice e a configuração plana ou convexa do osso frontal. Por meio desse método, Blumenbach chegava à conclusão de que a humanidade se dividia em cinco grandes categorias, subdivididas por sua vez em certo número de gêneros e tipos.

Embora Gobineau considerasse válidas as observações de Blumenbach, afirmava que os estudos craniológicos mais recentes, e, a seu ver, mais engenhosos, eram o do cientista americano Samuel Morton (1799-1851), o qual partia da ideia básica de que quanto maiores os crânios mais desenvolvidos se mostravam os indivíduos. Assim sendo, ao fechar com algodão todas as aberturas de crânios, esse pesquisador, enchia-os com grãos ressecados de pimenta e depois simplesmente comparava as quantidades contidas em cada um deles, formando tabelas nas quais constavam o número de crânios estudados, a média de grãos que comportavam, assim como seu máximo e o seu mínimo; evidentemente separando os ditos crânios de acordo com as categorias raciais que elegera, no caso, brancos, amarelos (mongóis e malaios), peles vermelhas e negros.

Apesar de elogiar o método de Morton, Gobineau teceu algumas críticas a ele, ao asseverar que esse pesquisador, ao dispor de crânios, utilizou na pesquisa para os brancos e peles vermelhas indivíduos muito dentro do tipo vulgar, enquanto para os negros e os de pele amarela tenha buscado indivíduos que eram chefes de tribos ou mandarins, 0 que produziu resultados incompletos, fortuitos e sem valor científico.

Baseado nos estudos de Morton, Carl Gustav Carus (1789-1869), médico e fisiologista alemão, subdividira os tipos humanos em quatro grandes grupos. Gobineau o criticava por separar mongóis e malaios em duas sub-raças diferentes quando a cifra média da capacidade craniana variava somente de 83 a 81 . Parecia-lhe que Carus procurava criar arbitrariamente uma quarta subdivisão tão somente para satisfazer a seu sistema.

Carus pressupunha que assim como o planeta passava por quatro estados: dia, noite, crepúsculos vespertino e matutino - a humanidade também estaria dividida em quatro grandes grupos: os povos brancos seriam os do dia, os negros, da noite, os amarelos, do crepúsculo da manhã, e os de pele vermelha, o crepúsculo da noite. ${ }^{20}$ Consoante essa análise, os europeus pelo esplendor de sua ciência e nitidez de sua civilização mantinham evidente relação com o dia, os negros dormiam nas trevas da noite, os amarelos eram dotados de uma existência social incompleta, os de pele 
vermelha estavam condenados ao desaparecimento. Sobre a figura de Carus, Gobineau estabeleceu que se tratava de uma mera comparação e não uma razão.

Até aquele momento, em seu Essai, Gobineau não expõe sua posição, mas porta-se como um árbitro, tão somente criticando de forma imparcial os argumentos que fundamentavam a tese dos poligenistas, sustentando que tais raciocínios não seriam suficientes para provar a existência de diversas espécies do gênero humano. Condição que não dava aos monogenistas, entretanto, a possibilidade de cantar vitória.

Os partidários do poligenismo, conforme apontava Gobineau, acossados por diversas objeções boas e más às suas teorias, resolveram não se ater somente aos estudos cranianos com o intuito de comprovarem as diversas origens do homem, todavia passaram a estudar o indivíduo humano por inteiro, como a forma da pélvis, a proporção relativa dos membros, a cor da pele e a natureza do sistema venoso.

Gobineau assinalava em seu Essai que o doutor Wilhem Vrolik (1801-1863), anatomista e patologista holandês e professor de anatomia e fisiologia na Universidade de Groningem, teria levado mais a fundo suas investigações sobre a pélvis, chegando à conclusão de que, entre os europeus, a diferença entre a pélvis do homem e da mulher era muito menos acentuada do que aquela verificada na raça negra, na qual, em ambos os sexos, se percebia um "caráter muito acentuado de animalidade". Tal sábio de Amsterdam, partindo do princípio de que a conformação da pélvis influi necessariamente na formação do feto, concluía que esse ponto se constituiria um indício de diferenças originais. Essa teoria foi atacada por certo Weber, ${ }^{21}$ para quem alguns indivíduos africanos e mongóis apresentavam pélvis de acordo com o padrão europeu. Gobineaua contra-argumentou, dizendo que Weber não levou em conta que nesses casos poderia ter havido alguma mestiçagem a influenciar no padrão.

Quanto à dimensão dos membros, os adversários da unidade da espécie deduziam ser o europeu melhor dimensionado e proporcional enquanto em outras nações se observava extremidades bastante delgadas, ao que os monogenistas alegavam ser isso fruto da ação do meio e do tipo de alimentação.

Gobineau citava também no Essai alguns argumentos dos dois lados sobre cor da pele, cabelo, mas o que considerava a cidadela científica dos unitários era o fato de seres humanos dos mais diferentes ramos serem capazes de produzir híbridos, e, mais do que isso, híbridos fecundos. Segundo ele, a observação feita pelos naturalistas é que mesmo que fosse possível a geração de híbridos entre espécies diferentes,eles seriam estéreis. Na percepção do conde, até aquele momento nenhum estudo havia sido realizado para verificar se essa regra se aplicava também à espécie humana, todavia conforme se tinha notícia, algumas mulheres nativas da Oceania, após serem fecundadas por europeus, já não se tornavam aptas a serem fecundadas por seus compatriotas. Esse fato poderia, a seu ver, ser um ponto de partida aos novos estudos.

Consoante observado nos parágrafos anteriores, Gobineau se encontrava suficientemente inteirado das discussões da ciência da sua época. ${ }^{22}$ Sua perspectiva, contudo, era bastante avessa às especializações em que a ciência moderna oitocentista se calcava. Antes disso, se dizia um homem do século décimo, em vez do décimo nono. Preferia não se ater a uma só área do conhecimento, entretanto, como típico enciclopédico, construía seu pensamento atravessando fronteiras de vários campos da ciência e condenando o que classificava como "a raiva da especialidade", que, no seu parecer, "causa estragos de maneira bastante calamitosa" à inteligência. ${ }^{23}$

0 conde não inventou o argumento racial, ele era de fato um assunto em pauta na filosofia, nas letras e nas artes e na ciência em geral do seu tempo. Analisar seu pensamento, sem levar em conta o calor da discussão que se travava nos meios eruditos europeus acerca dos novos continentes, dos seus habitantes, assim como a posição do europeu frente a eles, torna a figura de Gobineau caricatural e desprovida de sentido.

Claramente, neste artigo, faço questão de marcar minha posição de discordância quanto ao pensamento de Gobineau acerca das populações mestiças, no entanto é preciso analisá-las no contexto da ciência europeia oitocentista para não transformar o personagem em uma "avis rara". Essa visão nos legaria como prejuízo um entendimento estreito do personagem e da ciência de sua época, com a qual dialogava. 


\section{Esquecido por seus contemporâneos}

Ao observar a aceitação da obra de Gobineau, isto é, seus escritos de antropologia social ou literários junto a seus pares franceses, percebe-se que o conde, durante toda sua vida, buscou o reconhecimento como pensador sem nunca conseguir alcançar o sucesso. 0 próprio autor atribuía sua pouca aceitação ao fato de na Europa em geral, e mais especificamente na França, obras de valor terem se tornado cada vez mais raras e o público cada vez menos disposto à leitura:

Não tenho conhecimento de que haja grande novidade nas ciências e estou quase certo de que nada de novo se apresenta em literatura. Lê-se o menos possível e a maior parte das pessoas não lê mesmo nada; mas nem por isso celebra-se menos e em altos brados as grandezas do espírito moderno, de maneira que vai tudo absolutamente bem. ${ }^{24}$

Gobineau era um homem muito arrogante e de temperamento difícil. Um diplomata sem "meias palavras" e que pagou um preço alto por todas as inimizades que cultivou ao longo de sua carreira. Somente após a sua morte, seus escritos começaram a ser divulgados, e, mesmo assim, não a partir do seu país de origem, mas da Alemanha, por meio de Ludwig Schemann que foi apresentado à obra do conde pelo compositor Richard Wagner, com o qual Gobineau desenvolveu fraterna relação nos últimos anos de sua existência.

Ludwig Schemann dedicou sua vida a resgatar a obra e a figura de Gobineau, o qual foi bastante popularizado na Alemanha nazista, não obstante o conde jamais ter defendido um arianismo nos moldes do Nazismo conhecido no início do século XX. ${ }^{25} 0$ conde francês não poderia imaginar ou supor os rumos que o "gobinismo" tomaria na Alemanha nazista naquela época, mas, se tivesse dado crédito aos sábios conselhos de Tocqueville, não levaria avante uma opinião que, nas palavras do bom amigo, teria graves consequências, tais como liberar todo o mal da desigualdade permanente, acirrar o orgulho, a violência, o desprezo ao semelhante e a tirania.

Diante daquele bom conselho, Gobineau respondeu que se via como um médico ao deparar-se com um paciente terminal. Em vez de mentir, diria-lheque de fato iria morrer. Na visão do conde, contudo, não existiria qualquer nação que, sob qualquer pretexto, escapasse ao seu diagnóstico funesto. Todas elas se encontravam degeneradas em uma medida ou outra. Tal qual afirmou Léon Poliakov, a hierarquia racial de Gobineau deveria, pela lógica, destinar seu Essai às fogueiras do III Reich. ${ }^{26}$

\section{Gobineau, um monogenista sui generis}

Vale a pena entender qual era a posição de Gobineau quanto à unidade da espécie humana e verificar como 0 seu pensamento acabava por condenar os brasileiros a uma pena fatal. Conquanto muitos autores, de forma errônea, classifiquem Gobineau como um poligenista, ele acreditava ser o gênero humano fruto de um único casal. Este monogenismo de Gobineau é, no mínimo, sui generis ou, como afirmou Poliakov, "monogenista em teoria, e poligenista na prática". 27

Consoante 0 conde, a grande questão entre os que discutiam a origem única da espécie humana - monogenistas, e os que acreditavam haver os diversos tipos humanos surgido em diferentes lugares - poligenistas, era se desvendar 0 mistério da permanência dos tipos. Em outras palavras; se fosse comprovado que as forças da natureza, como o clima, o regime de chuvas, o tipo de solo, a alimentação etc. fossem capazes de produzir alterações étnicas ao longo de determinado espaço de tempo, os monogenistas tendiam a ganhar a batalha. Mas, na sua acepção, as raças humanas se encontravam encerradas em uma espécie de individualidade, que nada poderia fazê-las dela sair, a não ser pela mistura entre as mesmas. A possibilidade de gerar prole fértil era um forte indício contra a doutrina dos monogenistas. 
A permanência dos tipos é exemplificada ao afirmar que pinturas egípcias datadas de três mil anos, ao representarem judeus ou árabes, mostravam evidentes semelhanças com essas duas raças em seus dias, ainda que vivessem em climas bem diversos dos de então, como os judeus que viviam na Alemanha. É preciso notar que na opinião de Gobineau, assim como de outros homens de ciências resistentes ao darwinismo e ao evolucionismo em geral, o mundo não teria mais que 8 mil anos.

Gobineau asseverava que, de acordo com o relato das Sagradas Escrituras, não restava dúvida de que a humanidade teria sido gerada a partir de um único casal. Diante dessa afirmativa irrefutável e de sua crença na permanência dos tipos, ou fixidez das espécies, Gobineau elaborou uma tese capaz de amalgamar raciocínios díspares de forma a concluir o que já se constituía a priori, ou seja, a diferenciação entre os seres humanos seria inerente às raças.

Pregava que, nos primeiros tempos da criação, a energia climática era bem mais forte e ativa que em nossos dias. Tais forças naturais eram então capazes de sob sua pressão produzirem modificações étnicas. Além disso, os seres que se encontravam expostos àquelas forças naturais poderosas eram muito mais suscetíveis a mudanças que os seres atuais. 0 homem então criado não pertencia a nenhum grupo definido, como o negro ou o branco, tratava-se da "raça adamita", muito mais adaptável e menos fixa que as raças que vieram posteriormente sob a influência dos diversos climas. Tais raças, após ficarem isoladas nos diferentes sítios na Terra e depois que as forças "cosmogônicas" se tornaram mais brandas, passaram a guardar entre si relações muito débeis, como a necessidade de se comunicarem verbalmente mediante sons articulados pela voz, ou a possibilidade de engendrar híbridos fecundos.

A unidade primitiva da raça adamita teria se quebrado irremediavelmente produzindo-se assim as três raças secundárias: a branca, a amarela e a negra; as quais teriam seus caracteres físicos e psicológicos cristalizados e que somente poderiam ser alterados por meio do cruzamento entre elas. Essa fusão não se daria, entretanto, pelo somatório dos caracteres das raças originais, todavia fariam surgir novas características, tanto físicas como de temperamento, que levava ao início de novas raças, que seriam raças terciárias. Exatamente como adverte Gobineau no Essai:

Antes de irmos mais longe, convém que assinalemos uma lei: os cruzamentos não determinam unicamente a fusão das variedades, mas provocam a criação de caracteres novos, que resultam então no ponto mais importante, pelo qual podemos considerar o resultado um subgênero. ${ }^{28}$

A miscigenação das raças, tidas como terciárias, as quais já eram classificadas como um subgênero, resultava no surgimento deoutro grupo: as raças quaternárias. Nesse caso, consoante 0 autor, a mescla se daria com mais dificuldade, isto é, os híbridos quaternários demorariam mais tempo para se constituírem num grupo homogêneo, já que os caracteres "debilitados" no grupo terciário tenderiam a ficar mais "debilitados". Também as raças quaternárias poderiam se misturar entre si, e assim por diante, até que, nas palavras de Gobineau: "Assim, não se oferece nada, além de um espetáculo horrendo de anarquia étnica". ${ }^{29}$

Surpreendentemente, no final do livro I de seu Essai, Gobineau admite que nem todas as mesclas são más. Existem aquelas que se apresentam vantajosas: o gênero artístico, por exemplo, teria surgido mediante a mistura de brancos e negros. Da mesma forma, a variedade malaia surgida do cruzamento entre negros e amarelos teria formado uma variedade étnica mais inteligente do que as duas raças originais.

No entendimento do conde, a civilização somente seria possível mediante o encontro das raças e sua miscigenação. Contudo, na formulação do conde, "os pequenos são elevados, porém, desgraçadamente, os grandes decaem e essa consequência era irreparável" ${ }^{30}$ Conforme explica Gahyva (2006), o processo civilizador, na concepção de Gobineau, estaria inexoravelmente ligado ao cruzamento entre as raças, e vem daí seu pessimismo, pois nessa mistura também se encontra a degeneração que leva a humanidade rumo ao caos. 


\section{O Brasil e os brasileiros}

Se a França de seus dias já era medíocre aos olhos do conde, o Brasil deveria parecer-lhe a confirmação do pior dos pesadelos. Um país onde a mestiçagem racial alcançara um nível que já não se podia identificar claramente a constituição de cada um dos elementos que a compunham.

Consoante exposto no início deste artigo, o conde era, como os conservadores da sua época, crítico à Revolução Francesa, especialmente pelos ideais igualitários da doutrina das Luzes que se voltavam contra a tradição de uma sociedade na qual cada indivíduo ocupava o seu lugar e o seu papel demarcado. Para os conservadores, a ruptura com o passado e a tradição somente poderia gerar a desordem social e 0 caos.

Pensadores como Edmund Burke na Inglaterra ou Tocqueville na França perceberam o caráter universal da Revolução. Vozes se levantaram por toda a Europa, especialmente entre membros da Igreja Católica, aristocratas e monarquistas que resistiam ao caráter universal e individualista da revolução. Tocqueville assinalava em sua obra 0 antigo regime $e$ a revolução de 1835-1840:

Não havendo mais entre os homens nenhum laço de casta, classes, corporações, família, ficam por demais propensos a só se preocuparem com seus interesses particulares, a só pensarem neles próprios e a refugiarse num estreito individualismo que abafa qualquer virtude cívica. Longe de lutar contra esta tendência o despotismo acaba tornando-a irresistível, pois retira dos cidadãos qualquer paixão comum, qualquer necessidade mútua, qualquer oportunidade de ações em conjunto, enclausurando-os, por assim dizer, na vida privada. Já tinham a tendência de separar-se: ele os isola, já havia frieza entre eles, ele os gela. ${ }^{31}$

0 conde Gobineau, tal qual Tocqueville, não via com bons olhos as mudanças das quais a Revolução Francesa fora um marco.Tocqueville encarava o processo de queda do Antigo Regime como algo inevitável, conforme já explicitado no presente artigo. Contudo, pensava a democracia como uma forma de proteger a minoria da tirania de uma sociedade massificada e individualista. Gobineau, no entanto, ao atribuir todas as questões da história humana à raça, ou ainda à mistura de raças, apresentava uma visão bem mais pessimista. Voltava-se assim ao passado, acreditando que o futuro de toda a humanidade seria a degenerescência.

0 Brasil, na visão de Gobineau, seria o retrato mais claro disso. Em seu artigo ao Le Correspondant, o conde atribuía 0 alto índice de mortalidade infantil e todas as mazelas de um país escravocrata, no qual grande parcela da população não gozava de direitos civis básicos, a uma só razão: a miscigenação. Veja um trecho do citado artigo:

Ouvi estimativas muito mais baixas quanto ao total da população do Brasil, e alguns observadores que me pareciam competentes, e que apoiavam seus cálculos em deduções sensatas, não indicavam mais do que nove milhões de almas. Mais ainda, no espaço de trinta anos, o número de nove milhões foi o que sobrou de um total anterior de dez milhões. Consequentemente, em trinta anos um milhão desapareceu. É interessante conhecer este fato totalmente inexplicável. A grande maioria da população brasileira é mestiça e resulta de mesclagens contraída entre os índios, os negros e um pequeno número de portugueses. Todos os países da América, seja no norte ou no sul, hoje mostram, incontestavelmente, que os mulatos de distintos matizes não se reproduzem além de um número limitado de gerações. A esterilidade nem sempre existe nos casamentos; mas os produtos das raças gradualmente chegam a ser tão mal sãos e inviáveis que desaparecem antes de darem à luz, ou então deixam rebentos que não sobrevivem. O que se observa em São Domingos é o superlativo desta situação: mas, em todos os lugares onde o sangue mulato tende a se espalhar e a dominar os outros elementos étnicos, observa-se situação análoga. É inquestionável que, antes de cinquenta anos, todos os mulatos do Haiti terão desaparecido. No Brasil acabamos de ver que um período de trinta anos roubou um milhão de almas. ${ }^{32}$

Com base no raciocínio supracitado, o conde Gobineau chegou mais adiante à conclusão de que os brasileiros desapareceriam em menos de dois séculos. Vale lembrar que o pensamento do autor quanto aos mulatos não era ne- 
nhuma aberração aos homens de ciência da sua época. A suposta pouca fertilidade dos mulatos era bastante discutida, principalmente nos Estados Unidos, onde o poligenista Louis Agassiz propunha que a civilização branca suportasse a presença dos mulatos por algum tempo, uma vez que eles naturalmente desapareceriam, principalmente os que se encontravam em regiões de clima mais frio.

A proposta de Cabanis, já mencionada no presente artigo, na qual a miscigenação de raças ampliaria a Revolução do campo político ao biológico, deveria soar para o conde como a mais escandalosa das afirmativas. De acordo com Gobineau, a sociedade massificada que emergia politicamente após a Revolução Francesa já era algo indesejável. No campo biológico, a mistura racial, apesar de inevitável no processo civilizador, conduzia a humanidade ao caos.

A maneira pela qual o conde descrevia as chamadas raças quaternárias - "um espetáculo horrendo de anarquia étnica" -, era o retrato do pesadelo que o assombrava. Os brasileiros, aos olhos do conde Gobineau, personificavam a anarquia étnica, o caos que ele mais temia.

\section{Considerações finais}

Diversos autores já citaram o conde Gobineau, legando a este a alcunha de "pai do racismo moderno". 0 título dá a falsa impressão de que o francês teve grande aceitação em seus dias, o que, de fato, não aconteceu. Gobineau viveu sua vida no ostracismo, ressentindo-se de seus compatriotas por não terem dado a ele o tratamento que acreditava merecer junto aos grandes nomes de sua época.

Sua popularidade foi alcançada postumamente e deveu-se à divulgação de suas ideiasna Alemanhapor Ludwig Schemann, amigo de Richard Wagner, ou ainda pela interpretação e radicalização de seus escritos por parte do III Reich. Esse fato fez o autor tornar-se odiado pelo que escreveu, e mais uma vez pelo que the foi atribuído indevidamente, como, por exemplo, a crença de que pelo menos haveria uma raça ariana pura sobre a Terra.

Havia, entretanto, uns poucos que em vez de amplificarem as teorias racistas do conde tenderam a abrandá-las, como foi o caso de Alfred Dufréchou que, em 1908, incumbiu-se de apresentar Gobineau, já bemconhecido na Alemanha, aos franceses. Na compreensão deste autor, Gobineau, no Essai, pensava sob o signo do Imperialismo coletivo, ou seja, via a questão racial em termos de sociedade, já em Les Pléiades, romance por ele publicado em 1874, 0 conde defenderia um "arianismo simbólico", chamado por Dufréchou de Imperialismo individual. ${ }^{33}$

Nesse último caso, as virtudes da raça ariana não seriam vinculadas aos povos, mas aos indivíduos que se destacavam da massa da sociedade. Os chamados "fils de Rois". Assim, o conde teria abandonado uma crença racial baseada em conceitos fisiológicos e aderido à concepção de que existiriam indivíduos, como ele próprio, que traziam consigo a nobreza característica da raça ariana.

Seguindo a mesma linha de Dufréchou, Helga Gahyva em sua tese de doutorado (2006), recentemente publicada, acredita que o conde "sacrificou sua concepção de nobreza de raça em prol de uma mais abrangente" ${ }^{34}$ Na visão da autora, em vez de um racismo biológico, Gobineau vinculava-se a um conceito de linhagem.

Antes, porém, de demonizar ou absolver Gobineau por todas as consequências que as ciências racistas e racialistas produziram no mundo moderno, há que se estudá-lo no contexto do diálogo com as ciências de seu tempo e procurar entender em que bases esse autor proferia prognósticos que condenavam uma parcela da sociedade à decadência e ao desaparecimento, como o seu julgamento acerca dos brasileiros.

Gobineau, que tinha aversão à profissionalização do saber, circulava por diversas áreas do conhecimento, dialogando tanto com conceitos de linhagem que separava os franceses entre francos e gauleses quanto com a fisiologia e correntes evolucionistas de seu tempo. Para entender a sua controversa figura, é preciso levar em conta o debate de sua época no qual se inseriu, sem amplificar ou minimizar o seu evidente racismo que de maneira esplêndida foi denunciado ao próprio conde Gobineau pelo amigo Tocqueville. 
0 artigo publicado em 1874, no Le Correspondant,sobre a necessidade de imigrantes desejáveis para o Brasil, mostra que a percepção de Gobineau quanto à hierarquia das raças humanas permaneceu intacta ao longo dos anos. Essa hipótese é confirmada pelo próprio conde, ao surpreender-se com a boa recepção de seu romance Les Pléiades, escrevia ao amigo imperador em carta datada de 30 de julho de 1874: "Pretende-se que seja este meu melhor livro, mas seguramente não é; as Raças são superiores neste sentido". 35

Na ótica de Gobineau, suas convicções marcadas no Essai sobreviveram às críticas de Tocqueville, ao desprezo dos franceses, às ressalvas do imperador Pedro II e a todos os percalços que enfrentou durante a vida.

\section{Notas e referências bibliográficas}

Ricardo Alexandre Santos de Sousa é doutor em História das Ciências pela Casa de Oswaldo Cruz (COC/FIOCRUZ). E-mail: ricsousa14@gmail.com.

RAEDERS, Georges. 0 inimigo cordial do Brasil - o conde Gobineau no Brasil. Rio de Janeiro: Paz e Terra, 1988. p. 46.

Idem. D. Pedro /l e o conde de Gobineau. São Paulo: Cia Editora Nacional, 1938. p.90.

Idem, 1938, p. 75.

SOUSA, Ricardo Alexandre S. de. Agassiz e Gobineau - As ciências contra o Brasil mestiço. Dissertação (Mestrado em História das Ciências: História)Casa de Oswaldo Cruz (COC - Fiocruz), Rio de Janeiro, 2008.

5 ARENDT, Hannah. Origens do totalitarismo. São Paulo: Cia das Letras, 1990. p. 203.

6 D.PEDRO II, carta a Gobineau em 25 de dezembro de 1879. In: RAEDERS, Georges. D. Pedro Il e o Conde de Gobineau. São Paulo: Cia Editora Nacional, 1938. p.314

7 Para melhor entendimento dos intelectuais enciclopédicos e dos especialistas ver SÁ, Dominichi Miranda. A ciência como profissão - médicos, bacharéis e cientistas no Brasil (1895-1935). Rio de Janeiro: Ed. Fiocruz, 2006.p. 21-32.

8 Ensaio sobre a desigualdade das raças humanas, que a partir desse ponto será designado apenas como Essai.

$9 \quad$ D. PEDRO II, carta a Gobineau em 15 de novembro de 1879. In: RAEDERS, op. cit., p. 308.

10 TOCQUEVILLE, Aléxis. 0 antigo regime e a revolução. Brasília. Ed. UNB, 1997. p. 157.

11 GOBINEAU, Joseph Arthur. Ensayo sobre la desigualdad de la srazas humanas. Barcelona: Editorial Apolo, 1937. p. 14.

12 Idem, op. cit., 1937, p.15.

13 GAHYVA, Helga. Tocqueville e Gobineau no mundo dos iguais. Revista de Ciências Sociais. Rio de Janeiro, v. 49, n. 3, p. 553-582, 2006.

14 DEgROS, M. (Org.). Correspondance d'Alexis de Tocqueville et d'Arthur de Gobineau. Paris : Gallinard, 1959. p. 205.

15 Idem, op. cit., 1959, p. 213.

16 POLIAKOV, Leon. O mito ariano, ensaio sobre as fontes do racismo e dos nacionalismos. São Paulo: Ed. Perspectiva, 1974. p. 23.

17 GOBINEAU, Joseph Arthur, op. cit., 1937, p. 39.

18 POLIAKOV, Leon, op. cit., 1974, p. 198.

19 Idem, op. cit., 1974, p.200.

20 Conforme afirma Lorelai Kury, no final do século XVIII e início do século XIX, o conhecimento da natureza não era uma atividade exclusiva dos naturalistas, mas a prática da história natural era um aprendizado moral e uma forma de compreender a natureza humana e de se aproximar das leis que regem 0 Universo. Ver: KURY, Lorelai B. Histoire naturelle et voyages scientifiques (1780-1830). Paris: L'Harmattan, 2001.p.53. 0 tipo de paralelo entre as raças e as diferentes luminosidades do dia, utilizado por Carus, se enquadra nessa tradição científica.

21 Gobineau não informa a que Weber se refere.

22 Para examinar o diálogo de Gobineau com seus contemporâneos acerca das raças, ver: GOBINEAU, Joseph Arthur, op. cit., 1937, p.91-97.

23 GOBINEAU, carta a D. Pedro II em 6 de julho de 1871. In: RAEDERS, op. cit., p.54.

24 GOBINEAU, carta a D. Pedro II em 24 de janeiro de 1879. In: RAEDERS, op. cit., p.278.

25 SOUSA, Ricardo Alexandre S. de, op. cit., 2008, p. 141.

26 POLIAKOV, Leon, op. cit., 1974, p. 217.

27 Idem, op. cit., 1974, p. 218.

28 GOBINEAU, Joseph Arthur, op. cit., 1937, p. 116.

29 Idem, op. cit., 1937, p. 117.

30 Idem, op. cit., 1937, p. 152.

31 TOCQUEVILLE, Aléxis, op. cit., 1997, p. 46. 
RAEDERS, Georges, op. cit., 1988, p. 240-241.

33 DUFRÉCHOU, Alfred. Gobineau. In: Science et Religion: études pour le temps présent, 412 philosophes et penseurs. Paris: Bloud, 1907. Disponível em: <http://gallica.bnf.fr/ark:/12148/bpt6k68007j>. Acesso em: 24 fev. 2013.

34 GAHYVA, Helga. O inimigo do século: um estudo sobre Arthur de Gobineau (1816-1882). Tese (Doutorado em Ciências Humanas: Sociologia) - IUPERJ, Rio de Janeiro, 2006, p. 196.

35 GOBINEAU, carta a D. Pedro II em 30 de julho de 1874. In: RAEDERS,op. cit., p.166.

[Recebido em Setembro de 2012. Aprovado para publicação em Fevereiro de 2013] 